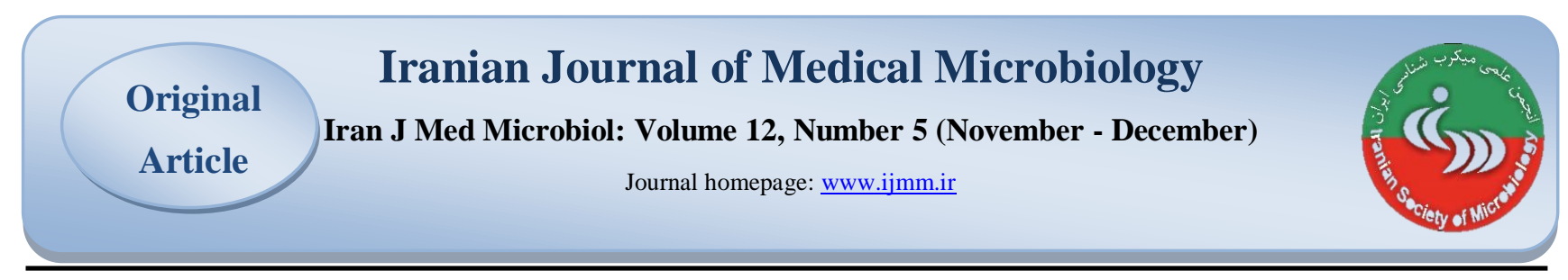

\title{
Molecular Identification and Serotyping of Isolates of Verotoxin Producing Escherichia coli Isolated from Urinary Tract Infection in Samples of Patients Referred to Health Centers in Khoy
}

\author{
Mahsa Abdolalizadeh, Changiz Ahmadizadeh* \\ Department of Microbiology, Faculty of Basic Sciences, Ahar Branch, Islamic Azad University, Ahar, Iran
}

\section{Article Information}

\section{Article history:}

Received: 2018/08/07

Accepted: 2018/11/27

Available online: 2018/12/22

\section{Article Subject: \\ Molecular Microbiology}

IJMM 2018; 12(5): 319-328

Corresponding author:

\section{Changiz Ahmadizadeh}

Assistant porfessor of Microbiology, Department of Microbiology, Faculty of Basic Science,Islamic Azad University, Ahar Branch, Ahar,Iran

\section{Email:}

ch-ahmadizadeh@iau-ahar.ac.ir

Use your device to scan and read the article online

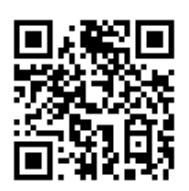

\section{Abstract}

Background and Aims: Urinary tract infections are among the most common infectious diseases. The bacterium of Escherichia coli, which produces verotoxin venom, is one of the most common causes of urinary tract infections. The aim of this study was to identify the molecular and serotyping of the isolates of E. coli producing verotoxin from the urinary tract infection in patients referred to the health centers in Khoy.

Materials and Methods: 200 urine samples of people suspected to urinary tract infection were identified by using standard culture and biochemical methods of $E$. coli. The bacterium was isolated in term of the susceptibility pattern to antibiotics and was studied using disc diffusion method. To do Serotyping, strains with polyvalent antisera were tested. DNA was isolated from bacteria after extraction. The Verotoxin producing isolates were identified by Multiplex PCR.

Results: 78 urine samples were identified as E. coli. E. coli isolates had the most antibiotic resistance to ampicillin and had the highest susceptibility to Norfloxacin. In serotyping, Group 3 had the most common strains of $E$. coli. Among the samples that were studied using Multiplex PCR and specific primers, stxl genes were observed in 3 isolated isolates and st 2 genes were observed in 16 isolated isolates and both stxl and stx 2 were seen in 9 isolates.

Conclusions: Serotypes of O25, O78, O103, O118, O124, O145, O157 and O164 were the most frequent infection-specific serotypes. The frequency of $E$. coli strains with stx2 gene producing verotoxin was more than stxl. High resistance to ampicilin is probably due to the excessive consumption of these antibiotics. Norfloxacin can be an appropriate choice for the treatment.

Keywords: Urinary tract infections, Escherichia coli, Verotoxin, Serotyping

Copyright @ 2018 Iranian Journal of Medical Microbiology. All rights reserved.

How to cite this article:

Abdolalizadeh M, Khojaseh E. Molecular Identification and Serotyping of Isolates of Verotoxin Producing Escherichia coli Isolated from Urinary Tract Infection in Samples of Patients Referred to Health Centers in Khoy. Iran J Med Microbiol. 2019; 12 (5) :319-328 


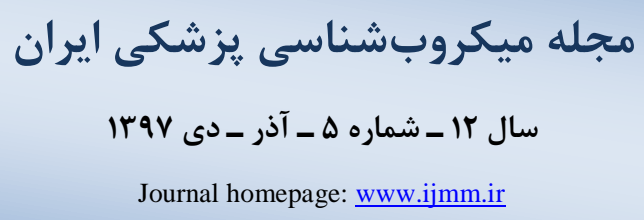

\section{شناسايى مولكولى و سروتايِينگ ايزوله هاى اشريشياكلى مولد وروتوكسين جداشده از عفونت ادرارى بيماران مراجعه كننده به مراكز درمانى شهرستان خوى}

"مهسا عبدالعلىزاده، جنغيز احمدى زاده"

1. كروه ميكروبيولوزى، دانشكدة علوم پايه، دانشخاه آزاد اسلامى واحد اهر، اهر، ايران

\section{جكيده}

زمينه و هدف: عفونتهاى ادرارى بلعنوان يكى از شايعترين بيمارىهاى عفونى محسوب مىشود. باكترى /شريشياكلى مولد

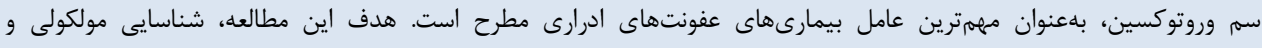

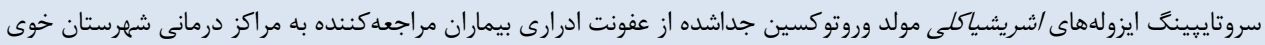

مواد و روش كار: تعداد . . ب نمونه ادرار افراد مشكوك به عفونت ادرارى، از طريق روشهاى كشت و بيوشيميايى استاندارد

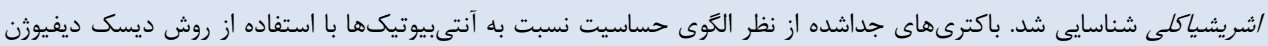

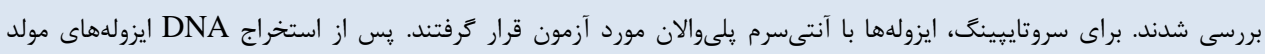

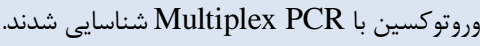
يافته ها: از كل نمونههاى ادرارى، لانمونه بهعنوان اشريشياكلى تعيين هويت شدند. ايزولههاى /شريشياكلى بيشترين مقاومت

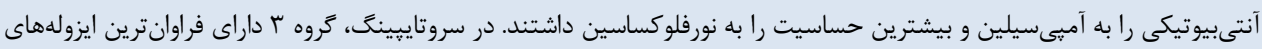

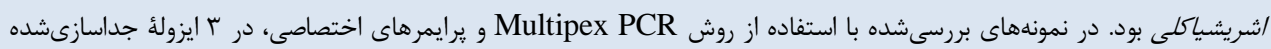

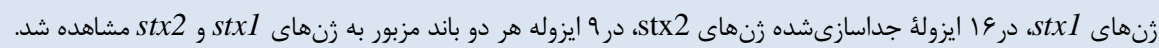

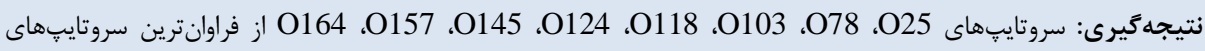

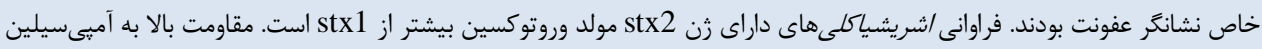

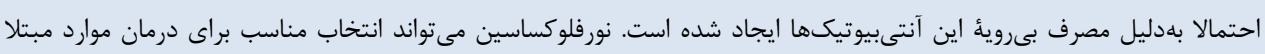
باشد.

$$
\text { كلمات كليدى: عفونتهاى ادرارى،/شريشياكلى، وروتوكسين، سروتايبينگ }
$$


اين زمينه كند (9). با توجه به اهميت پِيشگيرى و درمان بلموقع،

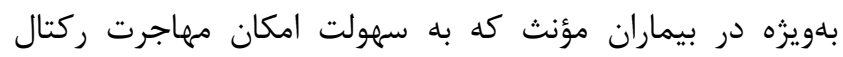

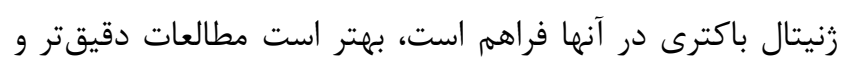

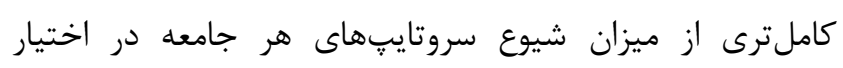

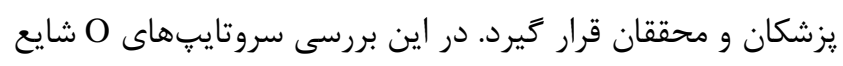

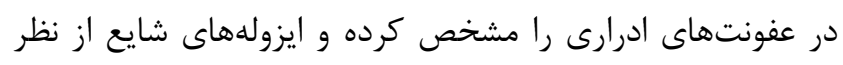

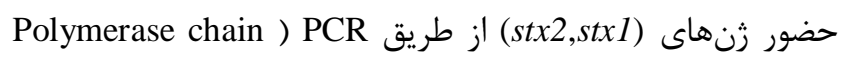
reaction

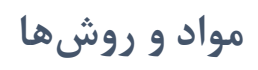

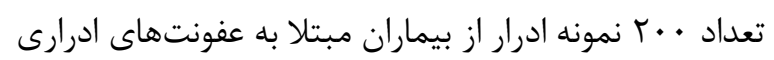

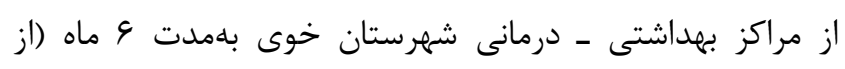

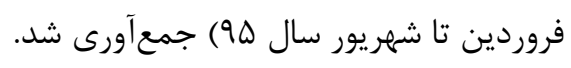

\section{كشت و جداسازى باكترى /شريشياكلى تهري}

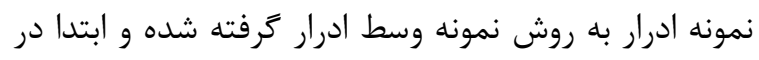

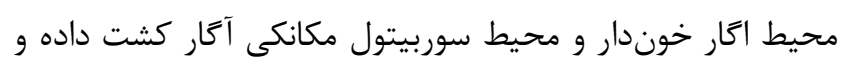

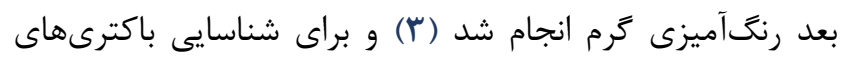

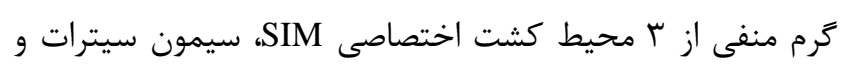

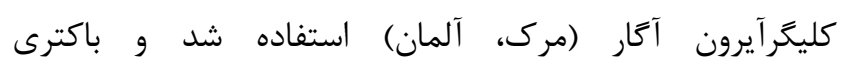

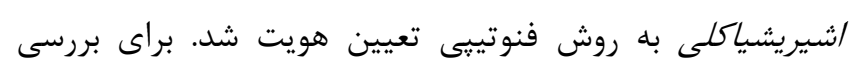

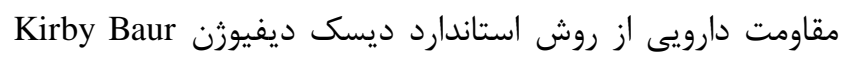

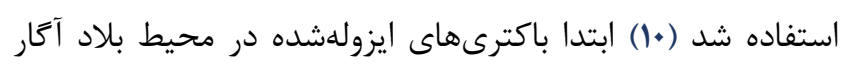

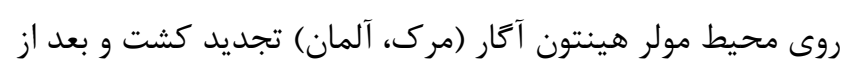

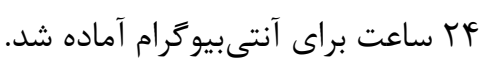

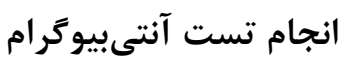

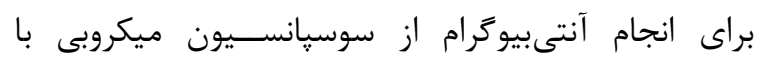

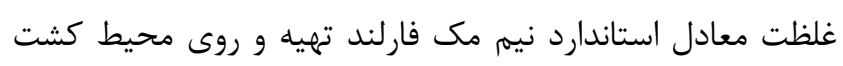

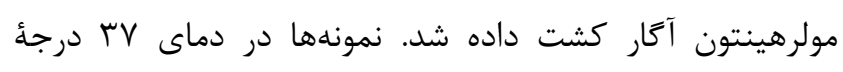

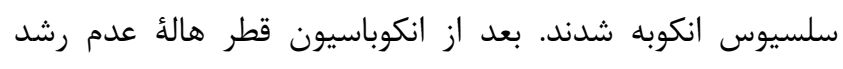

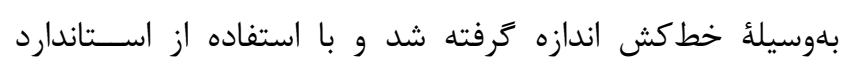

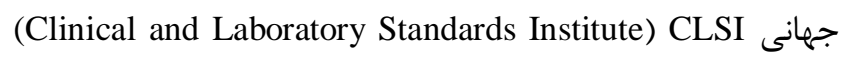

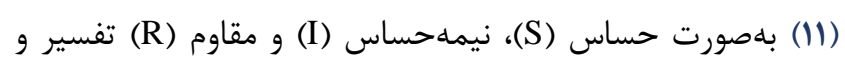

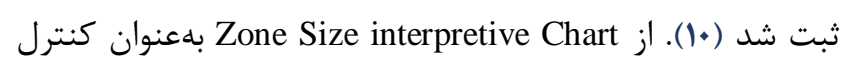

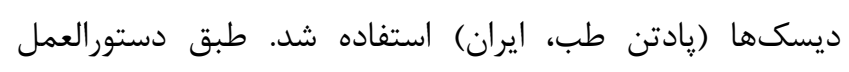

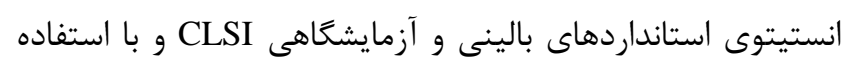

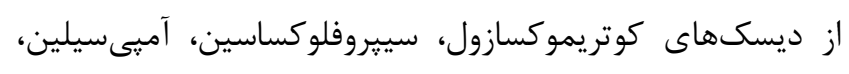

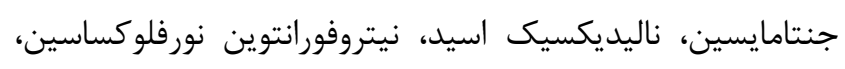

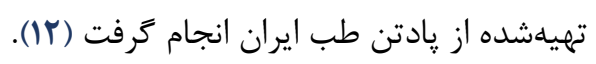

بيمارىهاى خطرناكى مثل سندروم هموليتيك اورميك و كوليت

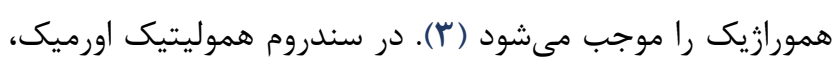

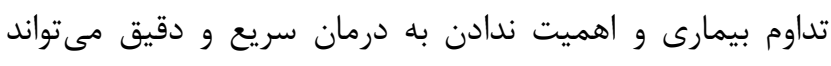

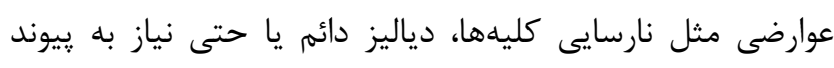

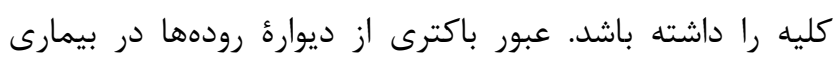

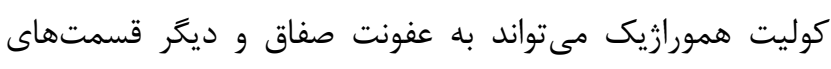

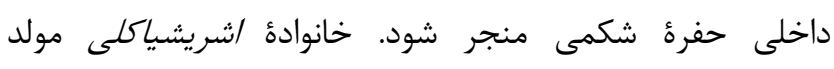
وروتوكسين شامل سروتايبهاى وسيعى از آنتىزن هائ O

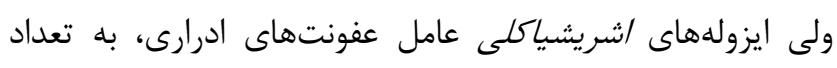
محدودى از سروتيبهاى حاوى آنتىزنهاى

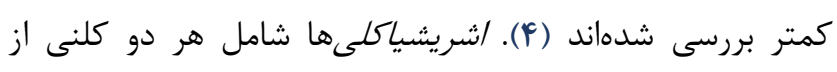

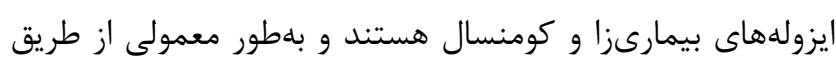

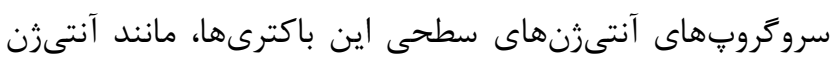

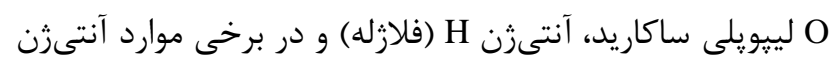

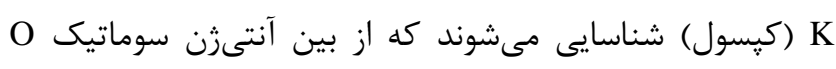
اهميت بيشترى نسبت به سايرين دارد. آنتىزن Oئنس

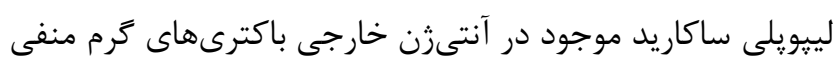

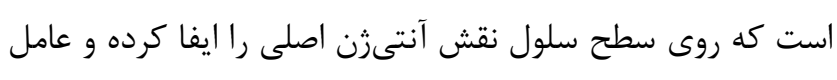

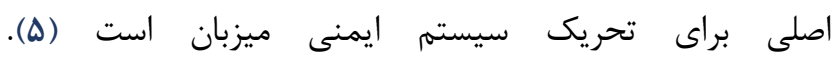
وروتوكسينهاى vtx1 و vtx2) توسط سه

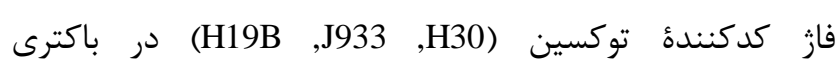

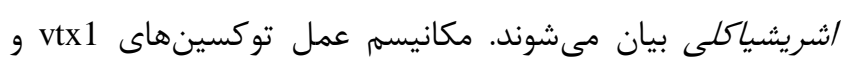

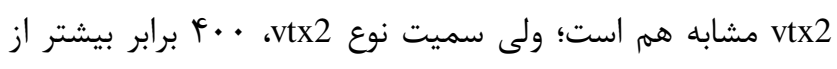

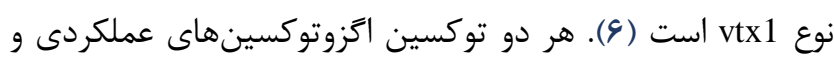

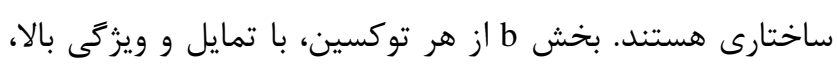
عامل اتصال به كيرنده اختصاصى كليكوليييدى به نه نام

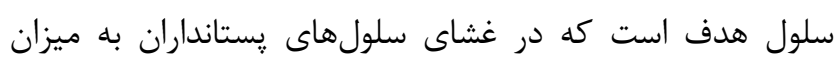

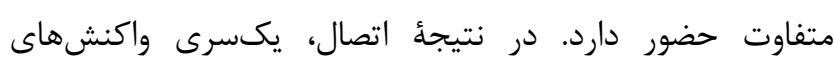

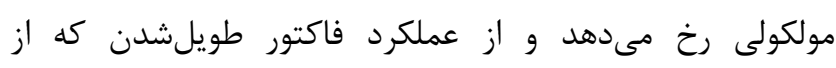

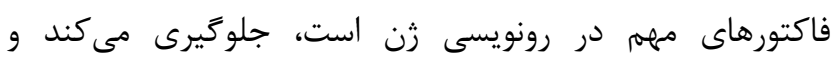

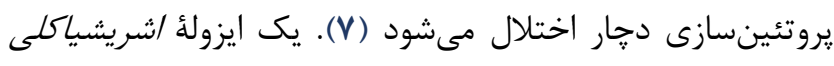

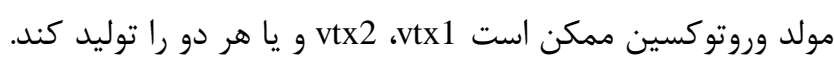

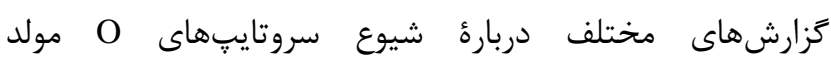

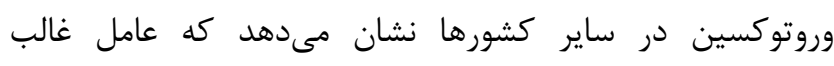

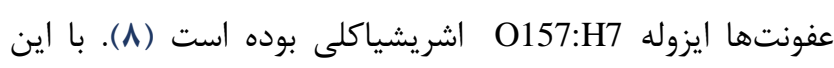
حال الكَى شيوع سروتايبهاى O Oيزوله ايزولههاى اشريشياكلى مولد

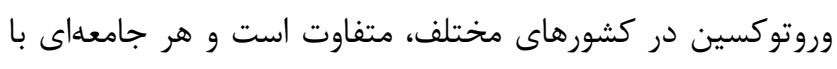

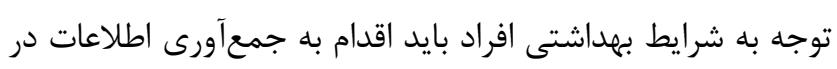


بر DNA ها انجام شد. براى انجام واكنش زنجيرهاى پيلىمراز،

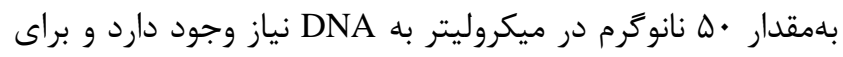
تعيين كيفيت و كميت DNA استخراجى با استفاده از دستخاه نانو دراب كميت و كيفيت DNA ارزيابى شد. واكنش زنجيرهاى يلىمراز، بهصورت مولتى يلكس براى زنهاى stx1 و stx2 انجام

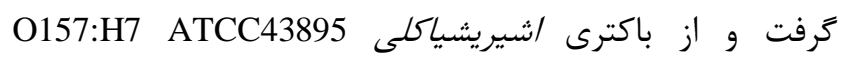

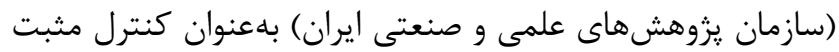
استفاده شد. مشخصات يرايمرهاى اختصاصى (تكايوزيست، ايران)

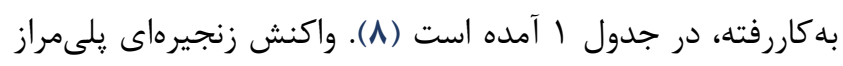

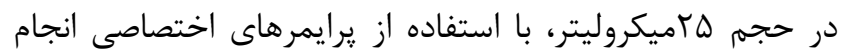

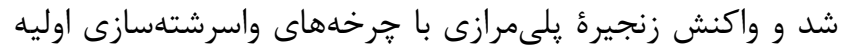

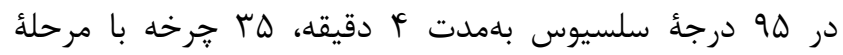

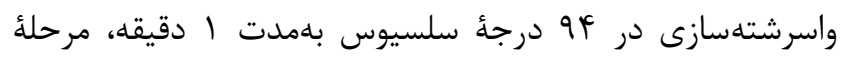

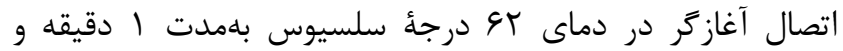

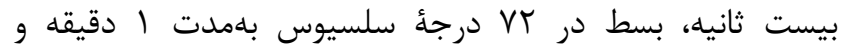

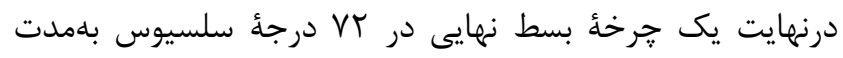

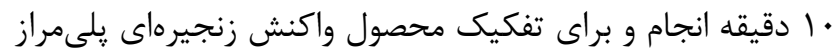

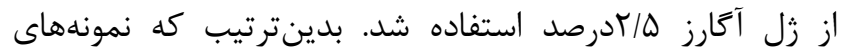

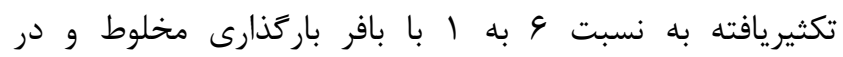
جاهكهاى زل بارَذارى شدند. رنغَآميزى در محلول اتيديوم

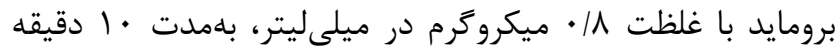
انجام يذيرفت. زل مدنظر بعد از رنگَآميزى و نوارهاى تكثير يافتئه

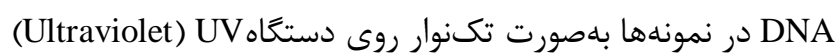
منتقل و عكسبردارى شد.

\section{سروتاييينَ ايزوله هاى اشريشياكلى}

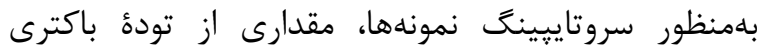

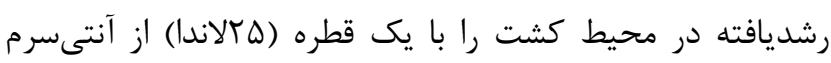
(فن طب سيوان، ايران) مخلوط كرديم و در مقابل نور و سطح تيره اسلايد را تكان داديم. بلعنوان كنترل منفى از يكى ميكروليتر سرم

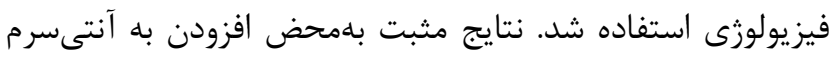

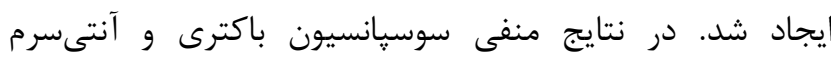
بلصورت نيمهشفاف باقى ماند و نتايج آكلوتيناسيون بلدست آمده

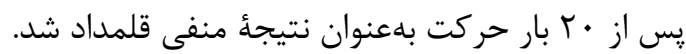

\section{واكنش زنجيرهاى يليمراز}

استخراج DNA با استفاده از روش كلروفورم ايزواميل الكل

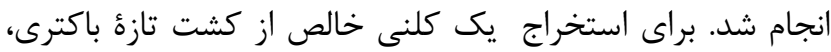
دماى هله درجه بهمدت · ل دقيقه انكوباسيون شد. سيس نمونهها

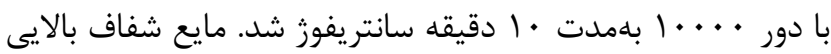
را به تيوب جديد انتقال داده و روى آن ايزويرويانل سرد به مقدار يكى سىسى اضافه شد و بهمدت يك ساعت در فريز قرار داده شد.

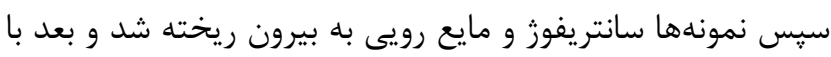

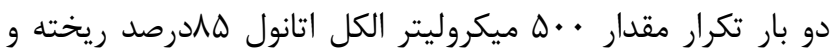

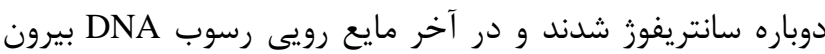

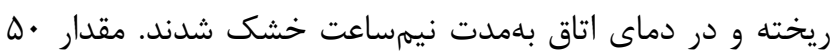

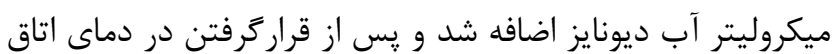
بهمدت نيمساعت براى تعيين كيفيت و كميت DNA الكتروفورز و

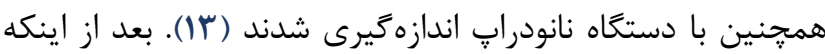
از تمامى نمونهها DNA استخراج شد، واكنش زنجيرهاى يلىمراز

جدول (. توالى نوكلئوتيدى ثرايمرهاى استفادهده (^)

\begin{tabular}{|c|c|c|c|}
\hline يرايمر مورداستفاده & توالى «يرايمر & دماى اتصال در مولتى يلكس & $\begin{array}{l}\text { اندازهٔ محصول } \\
\text { PCR }\end{array}$ \\
\hline $\begin{array}{l}\text { STX1 forward } \\
\text { STX1 reverse }\end{array}$ & $\begin{array}{l}\text { ATAAATCGCCATTCGTTGACTAC } \\
\text { AGAACGCCCACTGAGATCATC }\end{array}$ & \multirow{2}{*}{$62^{\circ} \mathrm{C}$} & $180(\mathrm{bp})$ \\
\hline $\begin{array}{l}\text { STX2 forward } \\
\text { STX2 reverse }\end{array}$ & $\begin{array}{c}\text { GGCACTGTCTGAAACTGCTCC } \\
\text { TCGCCAGTTATCGCATTCTG }\end{array}$ & & 255 (bp) \\
\hline
\end{tabular}

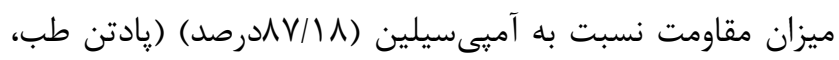

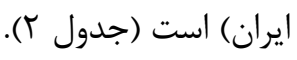

با توجه به نمودار ا، بيشترين فراوانى در كروههاى

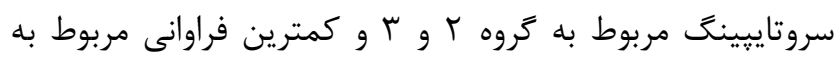

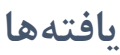

در مطالعؤ حاضر /شريشياكلى كه شايعترين عامل عفونت

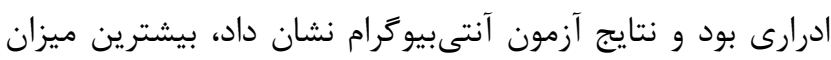

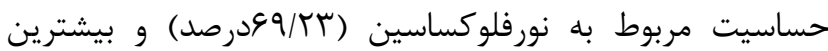




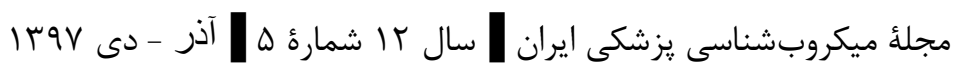

جدول r. فراوانى الكَوى مقاومت آنتىبيوتيكى ايزولههاى /شريشياكلى جداشده از عفونتهاى ادرارى شهرستان خوى

\begin{tabular}{|c|c|c|c|c|c|c|c|}
\hline \multicolumn{2}{|c|}{ نيمه حساس } & \multicolumn{2}{|c|}{ حساس } & \multicolumn{2}{|c|}{ مقاوم } & \multirow{2}{*}{ علامت اختصارى } & \multirow{2}{*}{ نام آنتى بيوتيك } \\
\hline درصد & ت تعداد & درصد & ت ت تعداد & درصد & ت تعداد & & \\
\hline r/A & r & $\Delta \cdot$ & rq & $\forall \& / 10$ & re & STX & كوتريموكسازول \\
\hline $1 \cdot / r \Delta$ & $\wedge$ & $\varepsilon \Delta / \mathcal{F}$. & Q1 & $T F / T \Delta$ & 19 & $\mathrm{CP}$ & سييروفلوكساسين \\
\hline $\mathrm{V} / \mathrm{V} \cdot$ & 4 & $D / I T$ & f & $\Lambda \mathrm{V} / \Lambda \Lambda$ & $9 \wedge$ & $\mathrm{AM}$ & آميىسيلين \\
\hline א & rq & $\Delta r / \Lambda F$ & er & IT/AT & $1 \cdot$ & GM & جنتامايسين \\
\hline$r \cdot / v \varepsilon$ & rF & $I V / 94$ & $1 f$ & $\Delta 1 / \Gamma$. & f. & NA & ناليديكسيك اسيد \\
\hline N/9V & V & $99 / T r$ & $\Delta f$ & rI/A. & IV & NOR & نورفلوكساسين \\
\hline$r \cdot / v V$ & TY & $1 \cdot / r \Delta$ & $\wedge$ & $\Delta \wedge / 9 \Lambda$ & fq & FM & نيتروفورانتوين \\
\hline
\end{tabular}

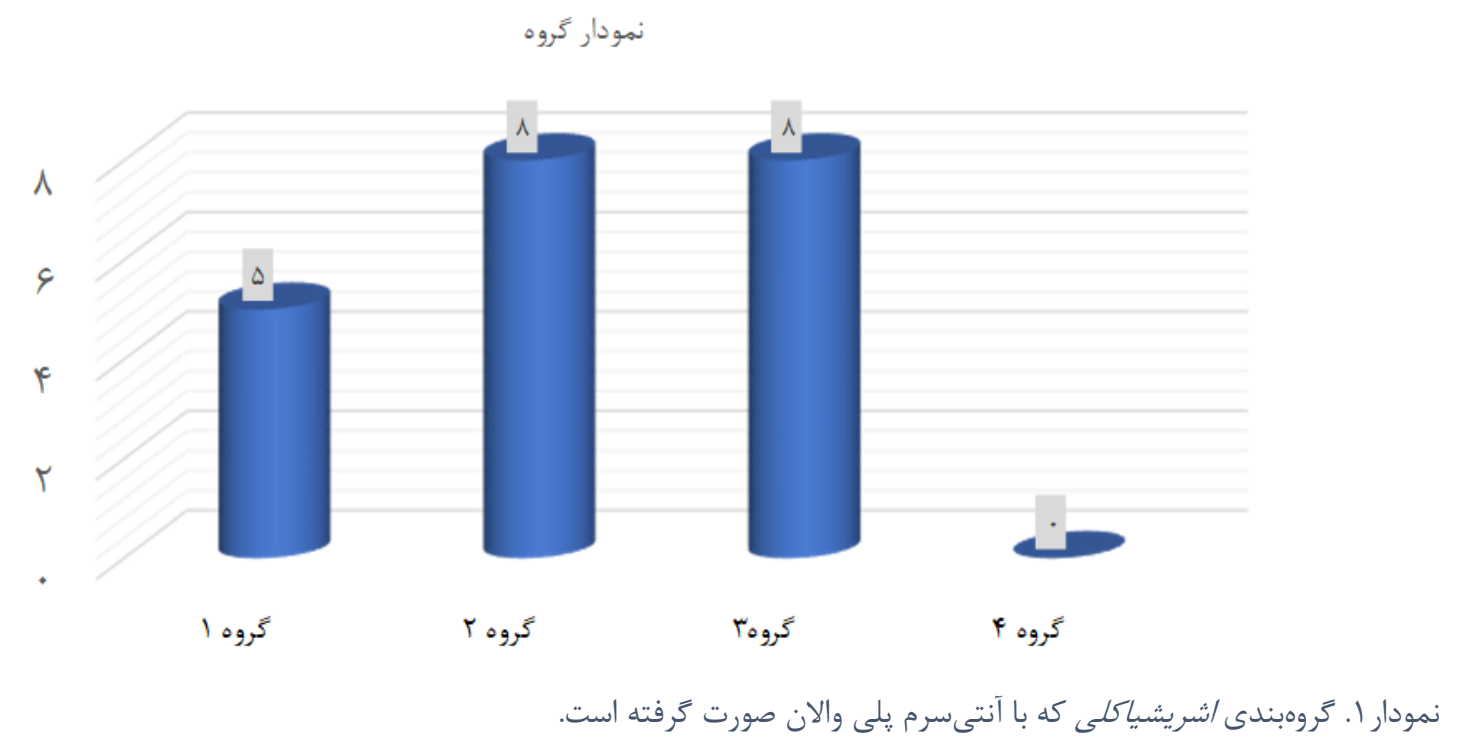

جدول r. نتايج سروتايبينگ گروههاى موردمطالعه

Anti Coli I

Anti Coli II

Anti Coli III
O55:K59, O86:K61, O91:K, O111:K69, O119:K69, O126:K71, O127:K63, O128:K67

O25:K11, O78:K80, O103:K, O118:K, O124:K72, O145:K, O157:K, O164:K

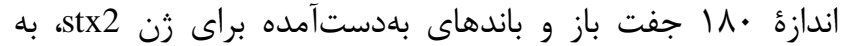

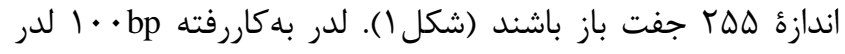

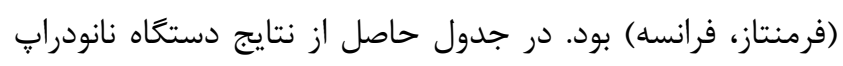
نشان داده شده است. نتايج واكنش زنجيرهاى يلى مراز نشان داد كه از نمونههاى جداشده (از نظر زن stx2, stx1)

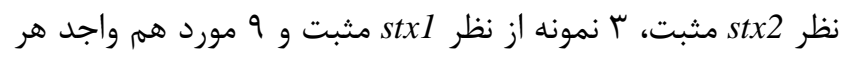

$$
\text { دو زن بودند (شكل r). }
$$

نتايج PCR

DNA بيشترين طول موج جذب RNA و يروتئين بلترتيب • بr و • • • نانومتر است وهمِ نمونههاى DNA استخراجى از كميت و كيفيت

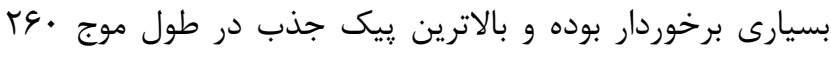

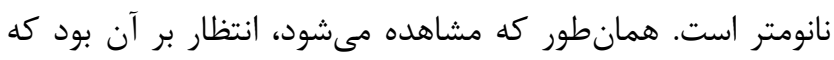
يس از انجام مولتى PCR قطعة تكثيرى براى زنهاى 


\section{$\begin{array}{llllllllllllllllll}L & \text { S1 } & \text { S6 } & \text { S8 } & \text { S15 } & \text { S24 } & \text { S27 } & \text { S35 } & \text { S42 } & \text { S46 } & \text { S47 } & \text { S51 } & \text { S62 } & \text { S67 } & \text { S71 } & \text { S103 }\end{array}$}
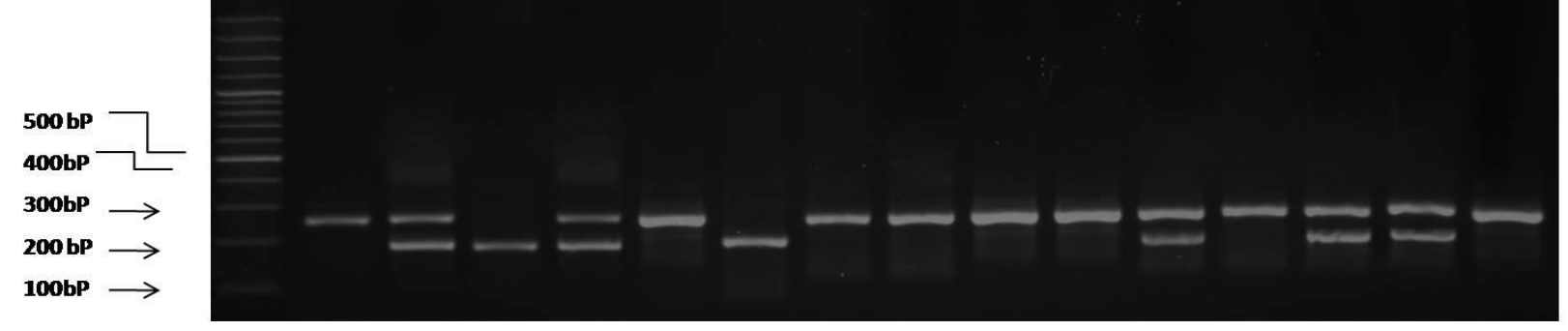

شكل 1. الكتروفورز محصول واكنش زنجيرهاى يلى Sراز براى نمونه هاى باكتريايى جداسازى

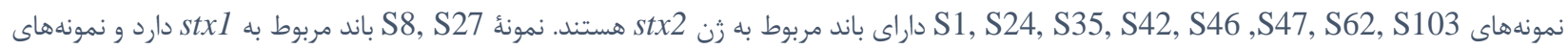
S6, S15, 151, S67, S71

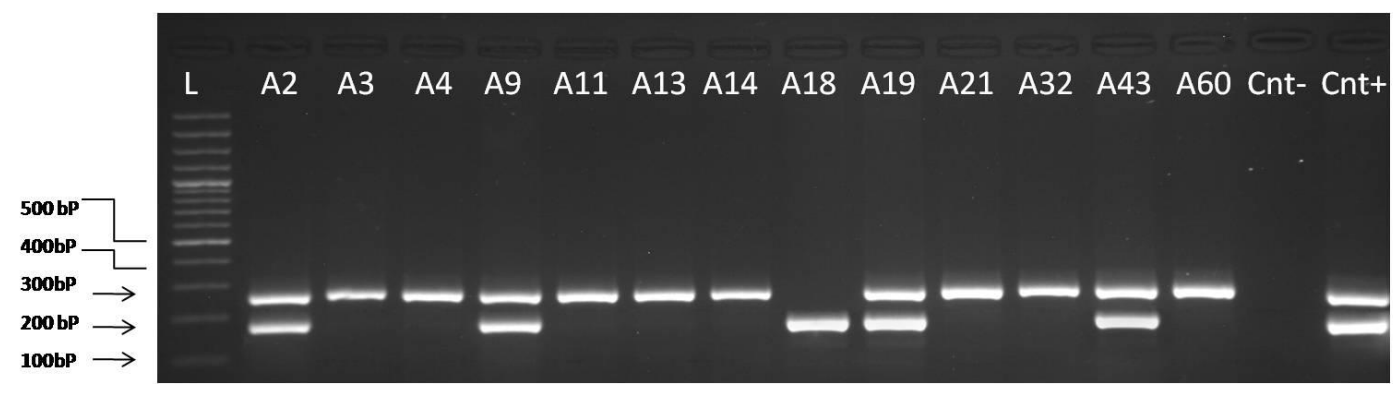

شكل ז. الكتروفورز محصول واكنش زنجيرهاى يلىمراز براى نمونههاى باكتريايىهاى جداسازىشده گروه SA

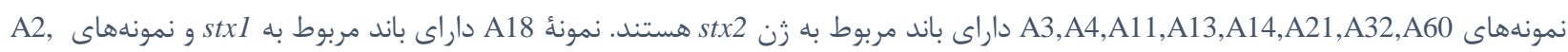

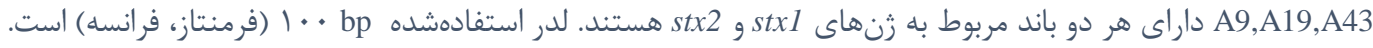

Eghbalian

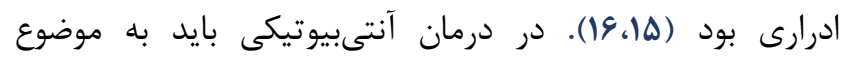

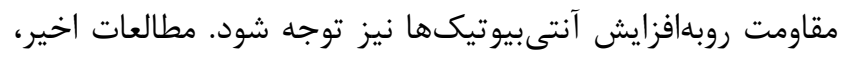

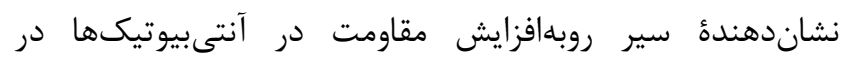

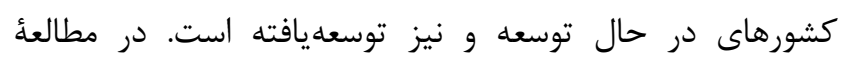
Ahmed

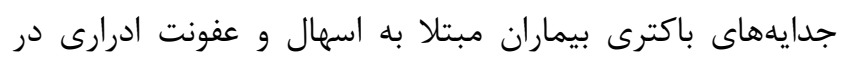

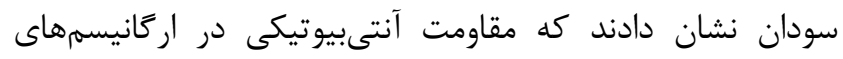

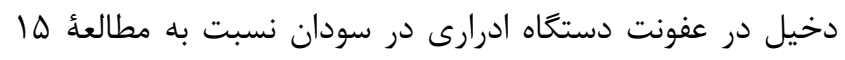

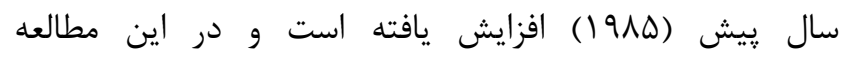

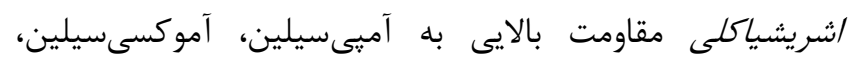

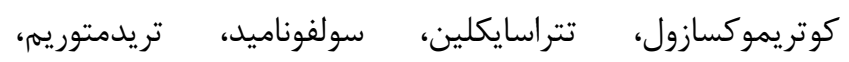

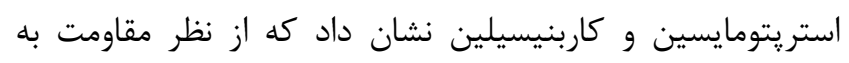

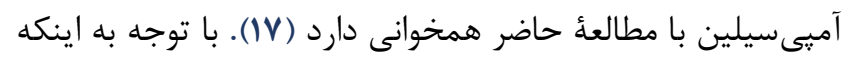

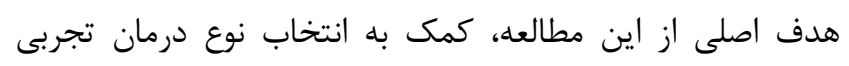

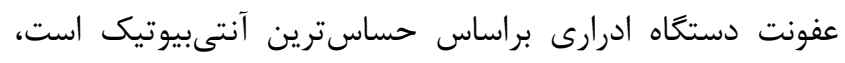

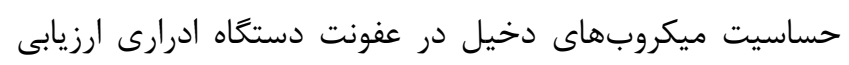

$$
\text { بحث و نتيجه تيرى }
$$

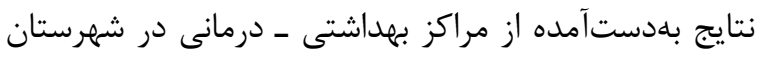

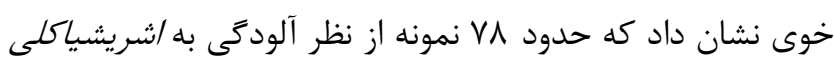
مثبت بودند. در اين مطالعه مشخص شد كه باكترىهاى خداى خانواده

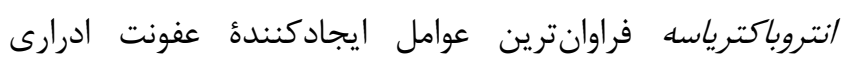

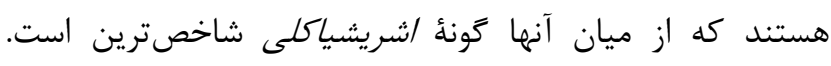
Isvand

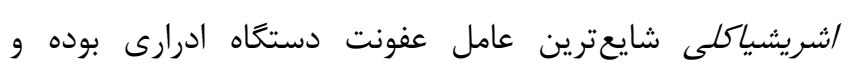

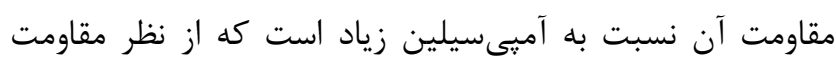

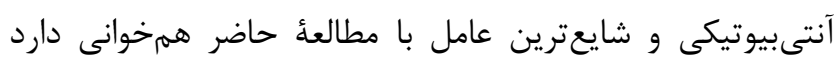

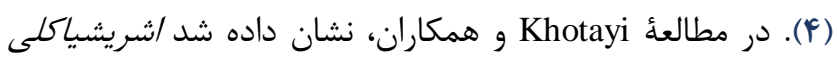

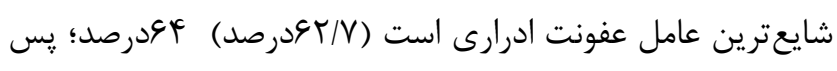

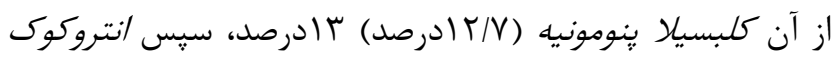
إن (N/N)

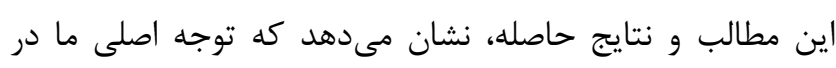

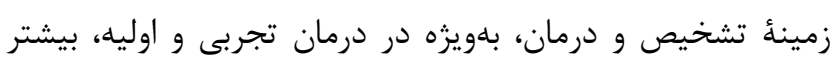

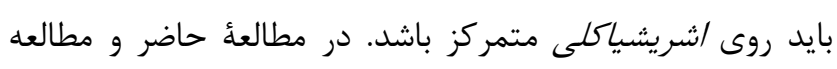


كزارش شد كه با مطالعُ حاضر همخوانى ندارد (ها). در مطالعأ Marefati نيتروفورانتوئين، ناليديكسيك اسيد و جنتامايسين و بيشترين

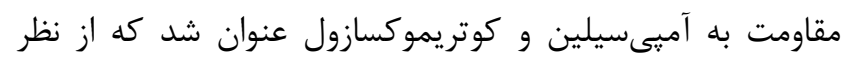
مقاومت در برابر آمبىسيلين با مطالعئ حاضر همخوانى دارد (T) (Y).

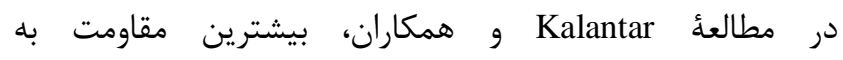

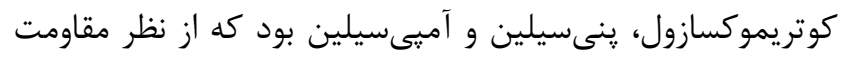

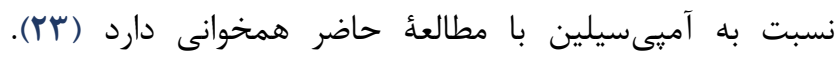
Mantadakis حساسيت ضدميكروبى از ياتوزنهاى ادرارى كودكان تركيه نشان

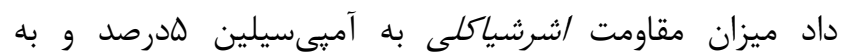

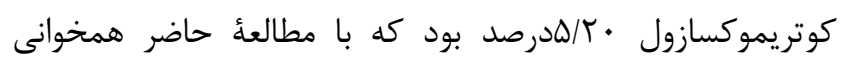

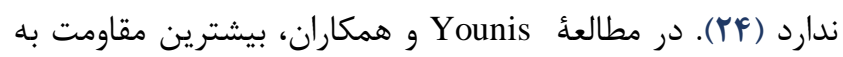

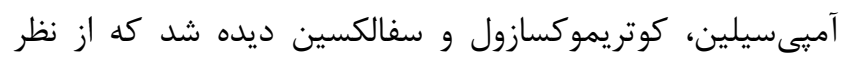
مقاومت نسبت به آمبىسيلين با مطالعؤ ما همخوانى دارد (Yه) (Yه).

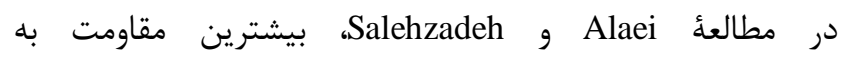
آميىسيلين، كوتريموكسازول و سفالكسين ديده شد كه از از نظر

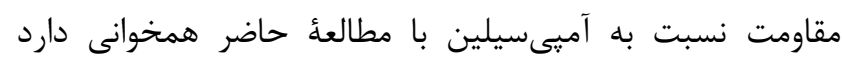

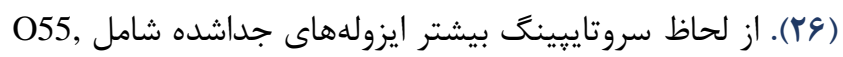
حان O86, O91, O111,O119, O126, O127, O128 جانسون طى يزوهشى سروگروهاى O Oداشده باكترى اشريشياكلى مولد عفونت ادرارى را در كشور امريكا O2,O4

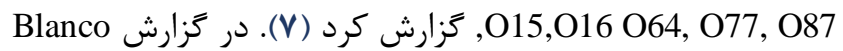

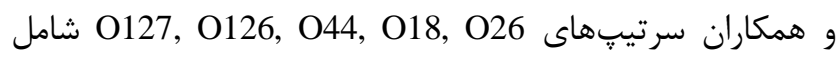

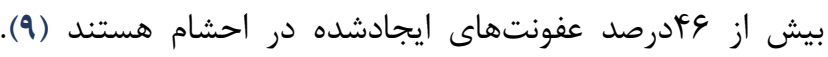

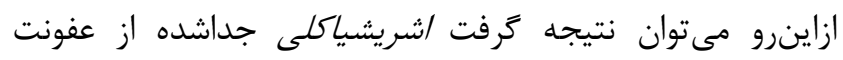
ادرارى در هر منطقة جعرافيايى با هم از لحاظ سرو تاييينَ

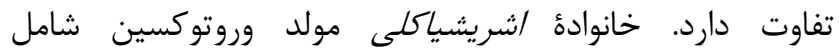

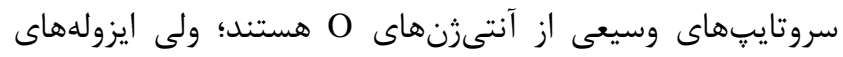

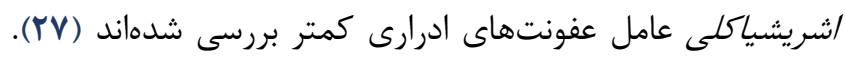

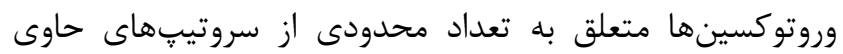

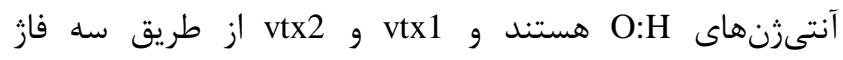
كدكنندة توكسين (H19B, 933J H30) در باكترى /شريشياكلى ونى بيان مىشوند. مكانيسم عمل توكسينهاى vtx1 و vtx2 مشابه هم

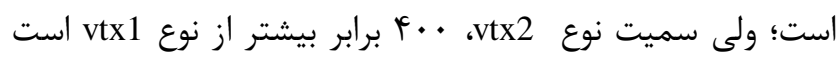

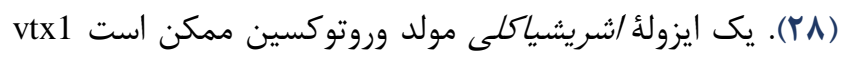
يا vtx2 و يا هردو را توليد كند. ززارشهاى مختلف دربارئ شيوع

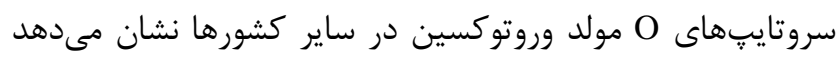

شد. در مطالعه حاضر /شريشياكلى كه شايعترين عامل عفونت

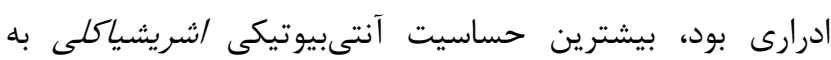

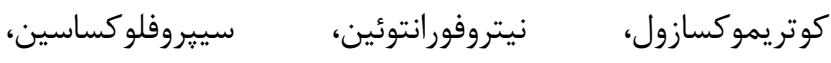

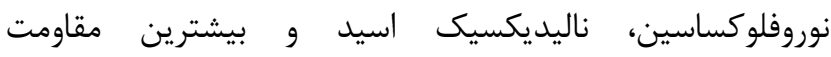
آنتىبيوتيكى به جنتامايسين، آمبيسيلين، است. Abdullahi و و Mehr Azamma

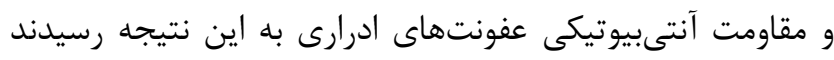

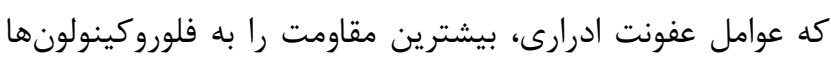

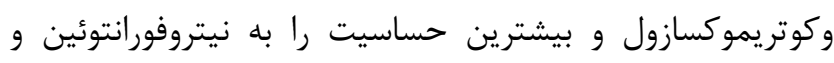

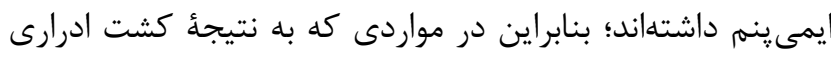

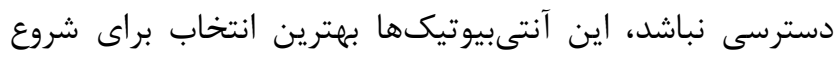

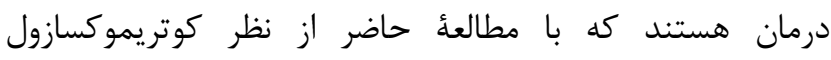

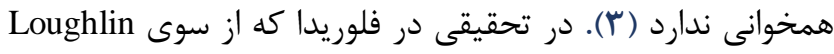

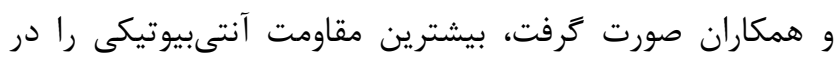

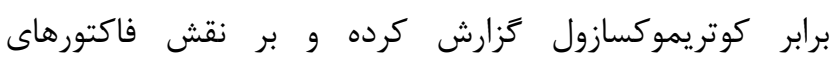

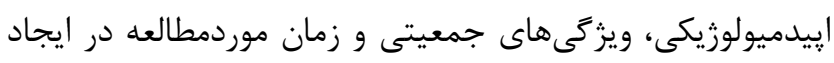

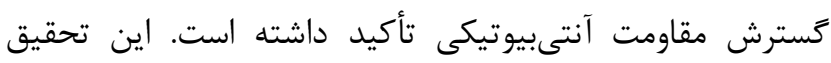

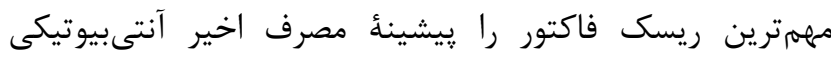

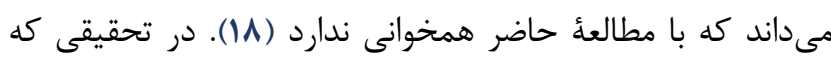

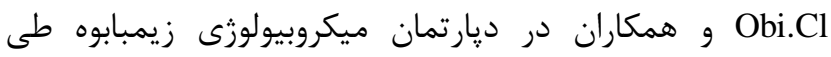

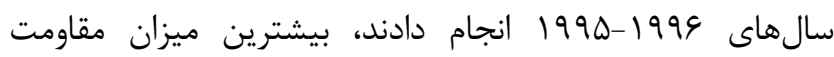

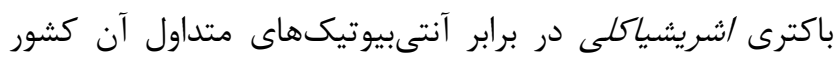

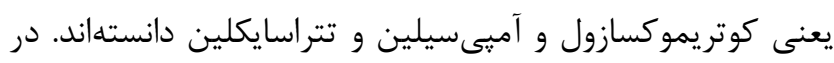

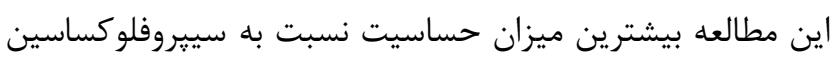

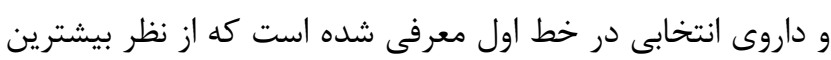

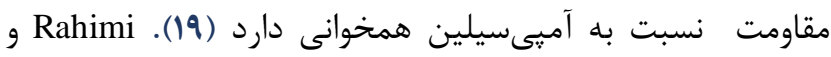

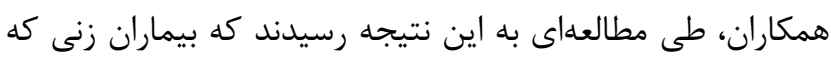

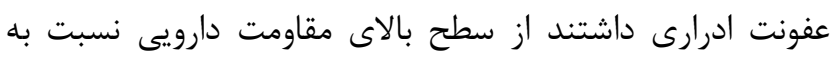

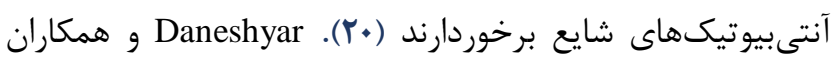

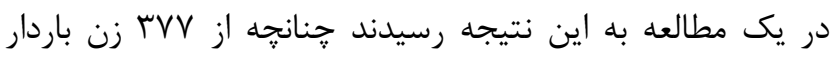

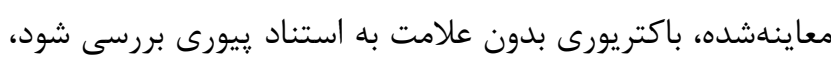

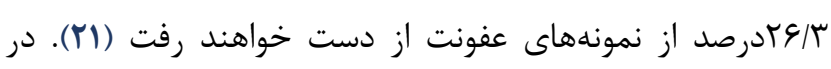

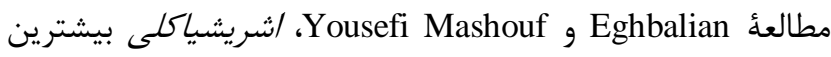
حساسيت را به نيترفورانتوئين، سييروفلوكساسين و آميكاسين و

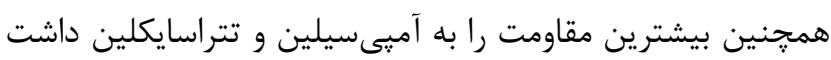
كه با مطالعه حاضر كاملا همخوانى دارد (1) (1). در مطالعأ Esmaeili سفوتاكسيم و آميكاسين و كمترين حساسيت به كوتريموكسازول 
مىبايست مطالعات دقيقتر و و كاملترى از ميزان شيوع سروتاييٍهاى هر جامعه در اختيار زيزشان و محققان قرار گيرد. بدينترتيب تشخيص بلموقع اين سويههاى باكتريايى، با توجه به

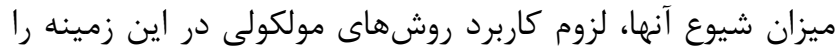
روشن مىسازد.

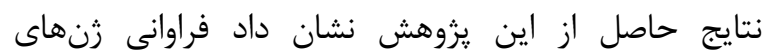
ويرولانس stx2, stx1 در ايزولههاى اشيرشيا كلى جداشده از عفونت ادرارى بالا است. زنهاى فوق مىتوانند بهعنوان هدف در مداخلات درمانى بررسى بيشترى شوند و همجنين نتايج آزمون

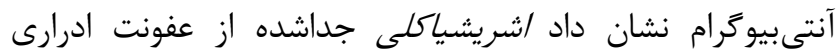
بيشترين مقاومت را به آنتىبيوتيك آميىسيلين داشت كه احتمالا بهدليل مصرف بىرويئ اين آنتىبيوتيكها ايجاد شده است.

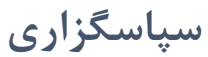

بدينوسيله از معاونت آموزشى و : يزوهشى دانشعاه آزاد اسلامى واحد اهر صميمانه سياسگزارى مىشود. تمامى كسانى كه در طول اجراى اين يزوهش مرا يارى كردند تقدير و تشكر مى كنم. شايان ذكر است كه اين مقاله حاصل يايان خامة كارشناسى ارشد

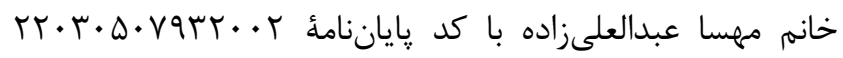
دانشعاه آزاد اسلامى واحد اهر است. تعارض منافع بين نويسند گان تعارض در منافع ززارش نشده است.

\section{References}

1. Schaechter M, Engleberg NC, DiRita VJ, Dermody TS. Schaechter's mechanisms of microbial disease. Lippincott Williams \& Wilkins. 2007.

2. Hamid farahani R, Tajik AR, Noorifard $M$, Keshavarz A, Taghipour N, HOSSIENI SJ. Antibiotic resistance pattern of E.coli isolated from urine culture in 660 Army clinical laboratory center in Tehran 2008. J Army Univ Med Sci. 2012; 10 (1) : 45-9.

3. Abdullahi AR, Mehr Azamma M. Evaluation of Antibiotic susceptibility and resistance pattern of urinary tract infections in Imam Khomeini Hospital. TUMJ. 2009; 7 (2): 59-66

4. Isvand A, Yahyavi M, Asadi SM, Kooti W, Davoodi JZ. THE Study of Bacteriological factors and Antibiotic resistance in women with UTI Referring to the Razi Laboratory Dezful. Jjums. 2014; 22: 199 - 205
كه عامل غالب عفونتها ايزوله O157:H7/شريشياكلى بوده است

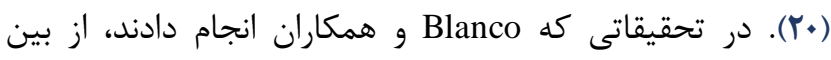
I أن FN جداسازى كنند (9). Wani طى ززارشى عنوان كرد كه فقط مورد

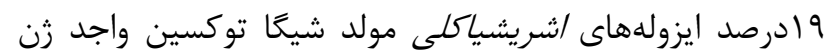

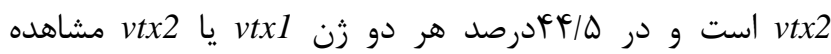

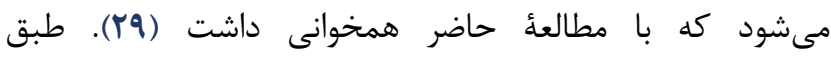
كزارشهاى Blanco اشريشياكلى مولد شيعا توكسى واجد زن وارسى هtxl، عسدرصد واجد زن 2tx2 و • سادرصد آنها داراى هر دو زن هستند كه با مطالعه حاضر همخوانى داشت (N). Jenkins و همكاران از طريق واكنش

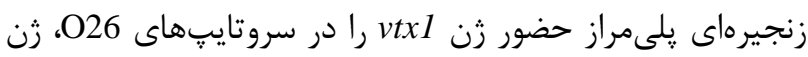

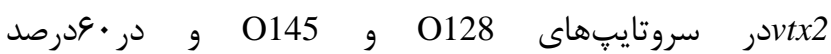
سروتايبٍهاى 0111 زن vtx2 و ^זدرصد آنها زن vtx1 را نشان دادند كه با مطالعئ حاضر همخوانى دارد (•r). در اين مطالعه ايزولههاى شايع از نظر حضور زنهاى (stx2 (stxl) از طريق واكنش زنجيره يليمراز بررسى شد. از نظر زن stx2, stx1 از بين نمونه نظر stxl مثبت بودند و 9 مورد هم واجد هر دو زن بودند. با توجه

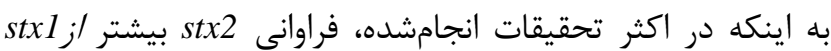

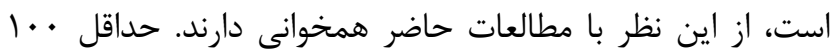

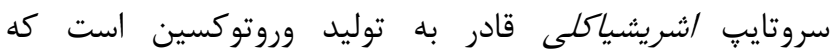

5. Sarkar S, Ulett GC, Totsika M, Phan MD, Schembri MA. Role of Capsule and O Antigen in the Virulence of Uropathogenic Escherichia coli . PLOS One. 2014 ; 9(4): e94786. DOI: : $10.1371 /$ journal.pone.0094786

\section{PMID: 24722484 PMCID PMC3983267}

6. Mansouri F, Shams N, Rashidian E. Prevalence of Shiga Toxin-Producing Genes in Escherichia Coli Isolated From Patients with Urinary Tract Infections in Khorramabad. Majallah-i pizishki-i Danishgah-i Ulum-i Pizishki va Khadamat-i Bihdashti-i Darmani-i Tabriz. 2015; 37(3): 50.

7. Johnson JR, Stell AL. Extended virulence genotypes of Escherichia coli strains from patients with urosepsis in relation to phylogeny and host compromise. J Infect Dis. 2000; 181(1): 261-72. https://doi.org/10.1086/315217

8. Blanco JE, Alonso MP, Mora A. Serotypes, virulence genes, and intimin types of Shiga toxin 


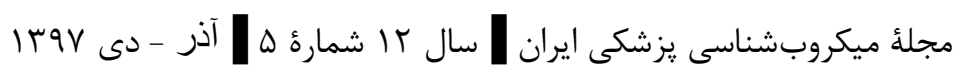

(verotoxin)-producing Escherichia coli isolates from human patients: prevalence in Lugo, Spain, from 1992 through 1999. J Clin Microbiol. 2004; 42(1): 311-19.

\section{PMID: 14715771 PMCID: PMC321739}

9. Blanco J, Blanco M, Blanco JE, Mora A, Alonso MP, Gonzalez EA, et al. Verotoxin-producing Escherichia coli in Spain: prevalence, serotypes, and virulence genes of $\mathrm{O} 157: \mathrm{H} 7$ and non-O157 VTEC in ruminants, raw beef products, and humans. Experimental biology and medicine. 2003; 228(4): 345-51.

10. Wikler MA, Cockerill FR, Craig WA, Dudley MN, Eliopoulos GM, Hecht DW, et al. Performance standards for antimicrobial susceptibility testing; Seventeenth Informational Supplement. CLSI. 2007; 27(1).

11. Cockerill FR, Patel JB, Alder J, Bradford PA, Dudley MN, Eliopoulos GM, et al. Performance standards for antimicrobial susceptibility testing; twenty-third informational supplement, M100-S23. CLSI. 2013; 33(1): 130-6.

12. Stamdards A. Performance standards for antimicrobial susceptibility testing. Approved Standards CLSI. 2010; M100-S20.

13. Mamiatis T, Fritsch EF, Sambrook J, Engel J. Molecular cloning-A laboratory manual. New York: Cold Spring Harbor Laboratory. 1982, 545 S., 42\$. Acta Biotechnologica. 1985; 5(1): 104. . https://doi.org/10.1002/abio.370050118

14. Khotayi Q, Mamishi S. Antibiotic resistance of germs isolated from urinary tract infections in Northern Iran . Iranian Journal of Pediatrics. 2002; 12(2): 28-32.

15. Esmaeili M. Antibiotics for causative microorganism of urinary tract infections.Iranian journal of pediatrics. 2005. 15(2): 165-73.

16. Eghbalian F, Yousefi Mashouf R. Determining the frequency of the bacterial agents in urinary tract infections in hospitalized patients under 18 years old in Ekbatan hospital. Journal of Army University of Medical Sciences of the I.R.Iran. 2005. 3(11): 635-9.

17. Ahmed AA, Osman H, Mansour AM, Musa HA, Ahmed AB, Karrar Z, Hassan HS. Antimicrobial agent resistance in bacterial isolates from patients with diarrhea and urinary tract infection in the Sudan. Am J Trop Med Hyg. 2000; 63(5-6): 25963.

18. Mc Loughlin T.G, et al. Antibiotic resistance patterns of uropathogens in pediatric emergency department patients. Clinical Practice J. (2002)21(3), 431-433.
19. Obi CL, Tarupiwa A. Simango C. Scope of urinary pathogens isolated in the Public Health Bacteriology Laboratory, Harare: antibiotic susceptibility patterns of isolates and incidence of haemolytic bacteria. The Central African journal of Medicine.1996; 42(8): 244-9.

20. Rahimi M, Falsafi S, Tayebi Z, Msoumi M, Mirzaei A,Farasat pour M. Antimicrobial susceptibility pattern of human pathogenic bacteria isolated from patients with urinary tract infection. Cellular \& Molecular Biology Letters. 2014; 4(15): 83-9.

21. Daneshyar E, Mousavi BS, Alikhani MY. Association Between asymptomatic bacteriuria and some emographic variables in pregnant womenr refered to health centers affilited to Hamadan university of medical sciences. jiums. 2010; 18(3): 53-60.

22. Marefati S, Ghazi saeidi M. The study of results of urine cultures and antibiograms in children with urinary tract infection referred to laboratory of Amir Kabir hospital of Arak. AMUJ. 2000; 3(12): 44-8.

23. Kalantar E, Motlagh ME, Limejad H, Reshadmanesh N. Prevalence of urinary tract pathogens and antimicrobial susceptibility patterns in children at hodpitals in iran. Clin Infect Dis. 2008; 3(3): 149-53

24. Mantadakis E, Tsalkidis A, Panopoulou M, Pagkalis S, Tripsianis G, Falagas $M$, et al. Antimicrobial susceptibility of pediatric uropathogens in Thrace, Greece. International urology and nephrology. 2011 1; 43(2): 549-55.

25. Younis N, AL-Nader M, Jbar I, Mardeni R. Uropathogens and their antibiotic susceptibility among children with urinary tract infection treated at prince Hashem Bin AL-Hussein hospital. JRMS.2010; 17(2): 41-5.

26. Alaei V, Salehzadeh F. The clinical manifestations and antibiograms relates in children with urinary tract infections. Journal of Ardabil University of Medical Sciences. 2008; 8 (3): 274-80.

27. Shamsi M, Roozbehani N, Kabir K.. Preventive behaviors of urinary tract infection (UTI) based on the theory of planned behavior among pregnant women in Karaj in 2013. Daneshvar. 2014; 21(108): 59-66.

28. Khalili MB, MK SY, Ebadi M, Sadeh MO. Correlation between urine analysis and urine culture in the diagnosis of urinary tract infection in Yazd central laboratory. Tehran University Medical Journal TUMS Publications. 2007; 65(9): 53-8.

29. Wani SA, Pandit F, Samanta I, Bhat MA, Buchh AS. Molecular epidemiology of Shiga toxin- 
producing Escherichia coli in India. Current Science. 2004; 25: 1345-53.

30. Jenkins C, Willshaw GA, Evans J, Cheasty T, Chart $\mathrm{H}$, Shaw DJ, et al. Subtyping of virulence genes in verocytotoxin-producing Escherichia coli (VTEC) other than serogroup $\mathrm{O} 157$ associated with disease in the United Kingdom. Journal of Medical Microbiology. 2003; 52(11): 941-7. 